\title{
Growing the green economy - globally
}

\section{Hazel Henderson}

\author{
P.O. Box 5190
}

St. Augustine, FL 32085, USA

E-mail: hhlibry@hazelhenderson.com

\begin{abstract}
Strategies for global sustainability and growing the green economy must address current economic models driving today's unsustainable forms of globalisation. Technological innovation is needed to shift from fossil fuels to renewable energy, recycling and redesign industrial processes. More fundamental strategy levels need re-examining: policy models, assumptions, institutional inertia and cultural values fuelling today's drive toward increasing unsustainability.

Conventional economic models still drive such unsustainability: the malfunctioning 'source codes' replicating traditional industrialism worldwide. This study reviews the current scientific debate about the unwarranted pre-dominance of economics in public and private decision-making; whether economics is a science or a profession and the demands by mathematicians, physicists and other scientists that the Bank of Sweden Prize in Economics be delinked from the original Nobel prizes. Scientific research on the human brain and ecosystems now refutes most of economics' core tenets. Multi-disciplinary policies and appropriate metrics beyond money coefficients are needed for steering societies toward sustainability and quality of life.
\end{abstract}

Keywords: economics; sustainability; systems; transdisciplinary; indicators; quality-of-life; values; environment; ecological assets; social capital.

Reference to this paper should be made as follows: Henderson, H. (2007) 'Growing the green economy - globally', Int. J. Green Economics, Vol. 1, Nos. 3/4, pp.276-298.

Biographical notes: Hazel Henderson is Futurist, Evolutionary Economist. She is the author of Beyond Globalization and many other books. She has also co-created the Calvert-Henderson Quality of Life Indicators, which are updated regularly at www.calvert-henderson.com. Her editorials are syndicated by InterPress Service to 400 newspapers in 27 languages. She holds many honorary doctorates, including from the University of San Francisco and Soka University in Japan. She served on advisory committees of the US Office of Technology Assessment, the National Science Foundation and the National Academy of Engineering, Washington, DC.

\section{Introduction}

As the effects of global warming confirmed the international scientific consensus, the new sectors of the green economy accelerated their growth worldwide. The renewable energy sectors: solar, wind, biofuels, ocean currents and tidal projects all received unprecedented funding by governments and private investors (Henderson, 2006). In 
addition, oil prices and geopolitical risks drove these investments in the green economy. In the USA, with government purse strings still controlled by fossil fuel and nuclear interests, venture capital provided seed funds for hundreds of new and startup companies in renewable energy, organic agriculture, new propulsion systems and energy storage devices, more efficient process controls, water purification, recycling and remanufacturing. As the 300 years of fossil-fuelled industrialism became increasingly non-viable and clearly unsustainable, a quiet worldwide design revolution is underway - largely unreported by mainstream media and their predominantly industrial paradigms. The price system, which excludes the growing 'externalities' of social and ecological costs, could not signal these true costs or the need for this wholesale re-design of production methods, infrastructure and consumption patterns. Thus, the early industrialisers, UK, Europe, the USA and other OECD member countries fell behind latecomers: China, India, Brasil and other developing countries not so committed to unsustainable economies. Brasil became energy-self-sufficient and leads the world in flex-fuel cars and ethanol from sugar cane wastes. China is committed to making its planned future growth sustainable and measured by a new 'green' GDP while its private sector has spawned some of the largest companies in solar, wind and organic foods. India is well-positioned to redesign its economy based on decentralised villages equipped with computers, communications and local off-grid solar electricity. While Europe and Japan are rapidly building their green economy sectors, the USA and Canada are still caught in their wasteful transportation, inefficient suburban sprawl and petroleum addictions. Thus, our new century is witnessing a profound global transformation, which behooves human societies to analyse their situations, belief systems and paradigms in fundamental ways.

The human family numbering now over six billion is clearly the most biologically successful species on planet Earth. We have evolved from our birthplaces on the African continent to colonise every part of Earth, consuming $40 \%$ of all its primary photosynthetic production - leading to the current and mass extinction of other species. We have conquered the oceans, the moon and outer space and now set our sights on Mars. To continue our spectacular technological success and preserve the options for our grandchildren's survival, we must now face ourselves and fearlessly diagnose our major failures: the fragmenting of human knowledge, the persistence of violent conflicts, wars and poverty. The UN Millennium Development Goals (Figure 1) provide an initial agenda. Fulfilling these Goals and shifting from fossil fuels to renewable resources and their sustainability can employ every willing man and woman on earth and expand global prosperity. Reintegrating human knowledge, systems thinking and multidisciplinary approaches to public and private decisions are widely recognised as necessary to address the human condition in this new century.

Reappraisals of the work of Charles Darwin together with new evidence from historians, archaeologists and anthropologist now clearly point to the evolution of human emotional capacity for bonding, cooperation and altruism. ${ }^{1}$ Competition, territoriality and tribalism, rooted in the fears of our past, served humans well in our early trials and vulnerability. So did cooperation and the ability to trust and bond with each other - influenced in all humans by the hormone oxytocin. Higher levels of this hormone during pregnancy and lactation bond women to their children, over the extended developmental period to maturity (Henderson, 2003a). Today, research by scientists from many fields, neurosciences, endocrinology, psychology, physics, thermodynamics, mathematics and anthropology have invalidated the core assumptions underlying 
economic models - which dominate public and private decision-making in most countries and multi-lateral agencies including the World Bank, International Monetary Fund (IMF) and the World Trade Organization. This new research reveals economics as a profession, not a science. Yet today, as privatisation and technological evolution speeds change and globalisation, economists and their general equilibrium models still drive these processes. While competition remains a key driver in evolution and all human affairs, cooperation and co-evolutionary processes are equally important. Social sciences study the full range of human behaviour - with the exception of economics, which assumes competition and self-interest are rooted in human nature (Figure 2, Full Repertoire of Human Behaviour).

Figure 1 Millennium development goals

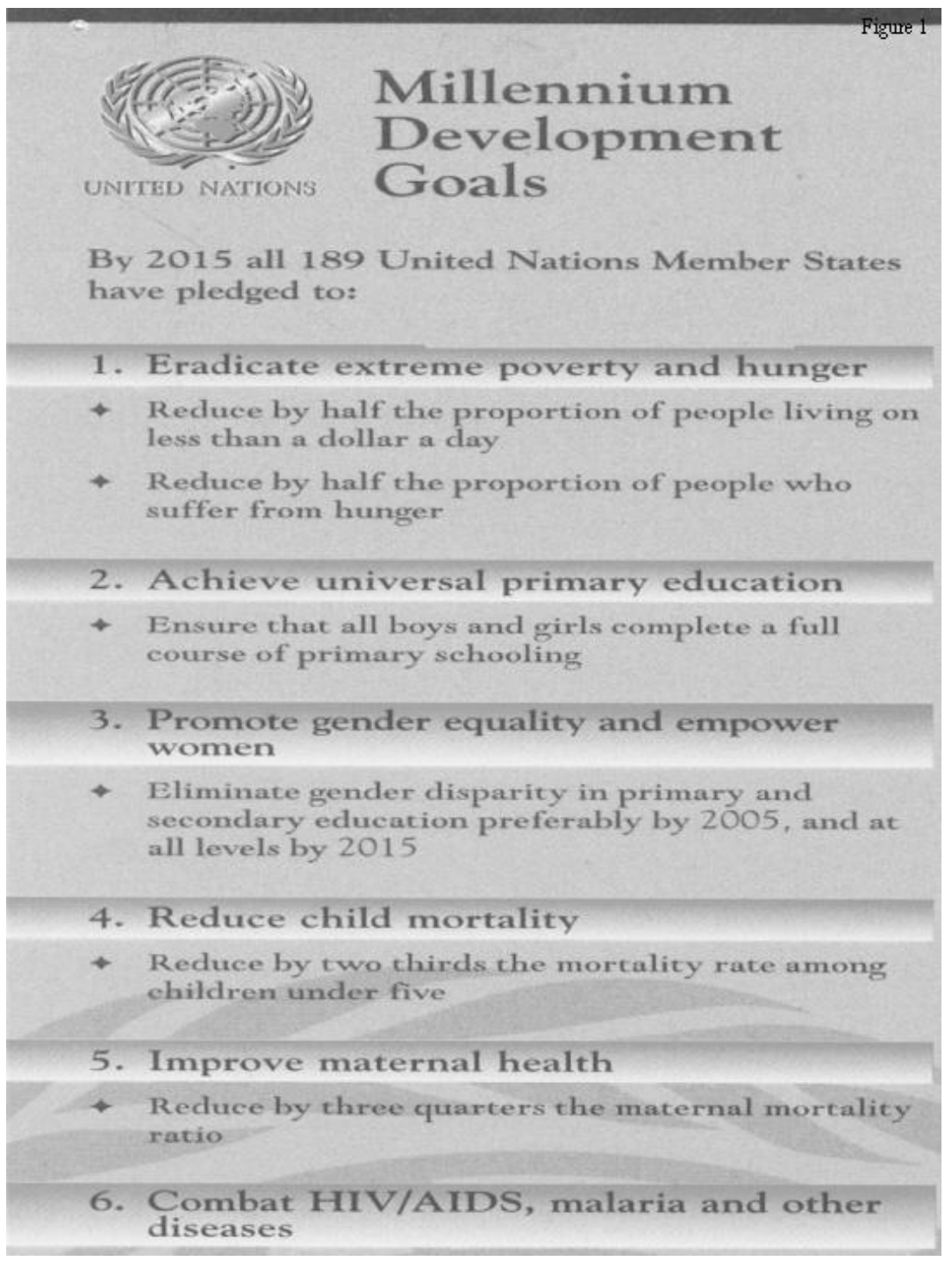


Figure 2 Full repertoire of human behaviour

\section{Repertoire of Human Behavior}

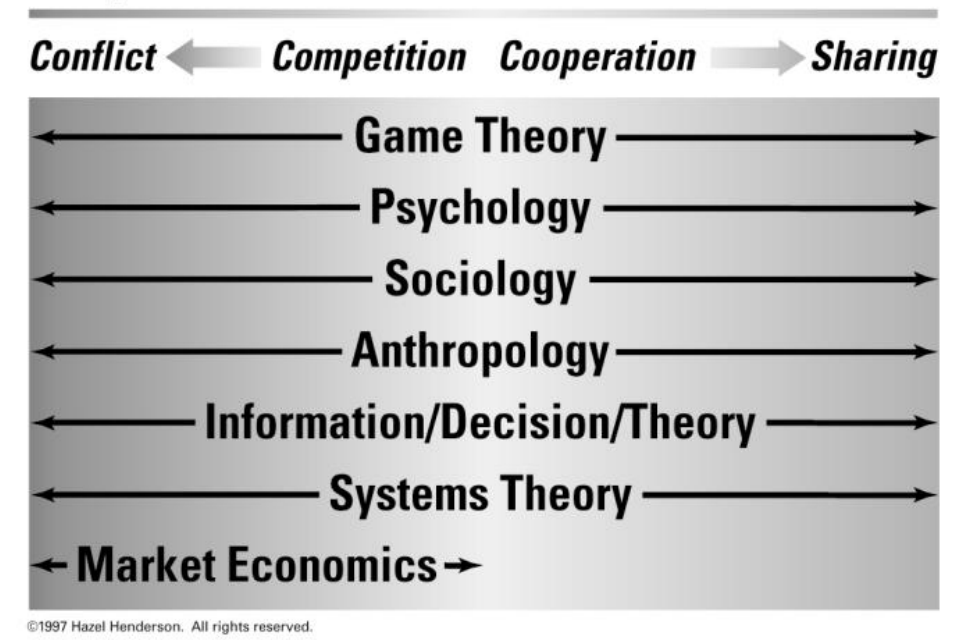

Political economy studies, as they were originally termed, rose to academic prominence after the publishing in 1776 of Adam Smith's great work An Inquiry Into the Nature and Causes of the Wealth of Nations. Invoking the scientific knowledge of the day, Smith related his famous theory of 'an invisible hand' that guided competition among self-interested individuals to serve the public good and economic growth. Smith drew parallels ascribing this pattern of human behaviour to Sir Isaac Newton's great discovery of the physical laws of motion. These principles of Newtonian physics can still be used to guide spacecraft to land on distant celestial bodies - most recently, Titan, one of Saturn's moons.

Economists of the early industrial revolution based their theories not only on Adam Smith's work, but also on Charles Darwin's The Descent of Man and The Origin of Species. ${ }^{1}$ They seized on Darwin's research on the survival of the fittest and the role of competition among species as additional foundations for their classical economics of laissez faire - the idea that human societies could advance wealth and progress by simply allowing this invisible hand of the market to work its magic. Polanyi's (1945) The Great Transformation and many other studies showed that Britain's nationwide market economy, in reality, was installed by Acts of Parliament. Yet, in class-ridden Victorian Britain, economists and upper-class elites espoused theories known as 'Social Darwinism': the belief that laissez faire competition and inequities in the distribution of land, wealth and income would nevertheless produce economic growth to trickle down to benefit the less fortunate. The benefits of competition in societies are widely-recognised - in spurring innovation, efficiency and driving industrialism and economic growth. The role of cooperation in families and communities was unpaid, unrewarded and invisible in economic models. Cooperation allowed for collective action, taxes and vital infrastructure for commerce. 
Charles Darwin also saw the human capacity for bonding, cooperation and altruism as an essential factor in our successful evolution (Loye, 2000). In retrospect, how otherwise could we have gone from the experience of over $95 \%$ of our history lived in roving bands of 25 people or less (Tainter, 1988) - to today's mega cities: Sao Paulo, Shanghai, Mexico City or Jakarta? These improbable metropolises, along with global corporations and governance institutions such as the United Nations and all its agencies, the European Union, now expanded to embrace 25 formerly warring countries - could never have emerged without humanity's capacities for bonding, cooperation and altruism.

So as we have evolved into our complex societies, organisations and technologies of today - we need to re-examine our belief systems and the extent to which they still may be trapped in earlier primitive stages of our development. Why for example do we underestimate our genius for bonding, cooperation and altruism - seemingly stuck in our earlier fears and games of competition and territoriality? Why do we over-reward such behaviour and still assume in our economic textbooks and business schools that maximising one's individual self-interest in competition with all others is behaviour fundamental to human nature? Why do the neoconservatives that drive most US policies today believe, as Margaret Thatcher proclaimed, that the individual has primacy over community? US society is already highly individualistic, whereas Mrs. Thatcher sought to rescue individualism from a more socialistic Britain. Scientific research is now revealing excessive individualism as dogma, while systems views, including those of Ken Wilber, Richard Slaughter, Fritjof Capra, Elisabet Sahtouris, Riane Eisler, Jane Jacobs, myself and many others seek a balance in acknowledging society, culture and the planet's ecosystems.

Why is our equal genius for bonding and cooperative behaviour - even altruism - not taught in business schools as the true foundation of all human organisations and our greatest scientific and technological achievements? In reality, as every business executive knows, competition and territoriality are channelled within structures of cooperation and networks of agreements, contracts, laws and international regulatory regimes that allow airlines, shipping, communications, and other infrastructure to undergird global commerce and finance. This reality is now recognised as 'Co-opetition', (Brandenburger and Nalebuff, 1996) but has not supplanted the competition model in economic theory. (Axelrod, 1984; Henderson, 1996; Moore, 1996; Wright, 2000) Thus, the formula for humanity's success has always rested on cooperation while embracing competition and creativity. Yet, shocking evidence documents ${ }^{2}$ that the very methods and curricula still taught in most business schools encourage managers in the kind of behaviour that produced the wave of corporate scandals and crimes at Enron, Worldcom, Parmalat, Tyco and Arthur Andersen. (Goshal, 2005) This debate in academia can be followed by accessing the publications of Sweden's Dag Hammarskjold Foundation ${ }^{3}$ and the French movement for 'post-autistic economics', covered in the LeMonde and at www.paecon.net.

What do deep, primitive beliefs about the primacy of competition and territoriality have to do with poverty, conflicts and wars? All are rooted in ancient human fears - of scarcity, of attacks by wild animals or other fearful bands of humans. Rooting out these fears - deeply coded in our 'us-versus-them' political and economic textbooks - is the essential task of our generation. We must move beyond this economics of our early reptilian brains - to include the economics of our hearts and forebrains. These old fears underlie today's continuing cycles of oppression, poverty, violence, revenge and terrorism. Indeed, if we humans do not root out these now-dysfunctional old fears, we 
will destroy each other. Politicians frequently use fear to manipulate consent. Yet fear can be counterproductive. Franklin D. Roosevelt during the Great Depression in the USA proclaimed that we have nothing to fear but fear itself.

Meanwhile, the fantastic potential humans have created for further successes through pursuing the greening of the global economy and the UN Millennium Development Goals and building prosperous, equitable, sustainable human societies is now within our grasp. The new 'superpower' of global public opinion is already rejecting the old dysfunctional dogmas. Over ten million people demonstrated peacefully worldwide against the pre-emptive war on Iraq. Yet as Kuhn (1962) described in his Structure of Scientific Revolutions, old dysfunctional beliefs often persist long after they have been disproved. ${ }^{4}$

So it is with today's political and economic textbooks and the entire paradigm underlying the 'Washington Consensus' model of development. We have evidence of its bankruptcy all around us: global warming, widening poverty gaps, the digital divide, unbalanced, unsustainable economies mired in debt - breeding despair and terrorism, diverting resources from enhancing human life to military weapons. Today, even military leaders acknowledge that many problems we face are not susceptible to military approaches. This new awareness reveals not a flaw in human nature - but a flaw in our encoding of our past in that set of dysfunctional beliefs that deny humanity's true genius - those cooperative, bonding and altruistic skills that have undergirded our progress to date. Dysfunctional beliefs are deeply entrenched in many of the models of economics that dominate our decision and public policies. This malfunctioning source code underlying economics focused on money circulation, is still replicating behaviours and organisational structures that imperil human survival under 21 st century conditions. The creation of money - from clay tablets, coins to electronic data - was a vital social innovation to track transactions beyond barter in early markets. Yet, money does not equate to wealth and today's high-tech electronic barter reminds us that money is merely one form of information - no longer needed in today's electronic barter transactions (Henderson, 2001).

Echoes of obsolete theories are still heard today and propounded in mainstream economic textbooks as theories of 'efficient markets', rational human behaviour as 'competitive maximising of individual self-interest', 'natural' rates of unemployment (codified as the NAIRU rule of central bankers) and the ubiquitous 'Washington Consensus' formula for economic growth (free trade, open markets, privatisation, deregulation, floating currencies and export-led policies). Lately, the US Federal Reserve Board's use of 'neutral' interest rates has been exposed by the Levy Institute as convoluted and favouring asset owners above workers' wages. ${ }^{5}$ Central banks' theoretical money-circulation models must be scrutinised because these institutions have won independence from political control and wield enormous power over societies. Monetary policy and money creation are now widely understood as political, not scientific (Leitaer, 2001).

Such unaccountable, obscure theories still underpin today's economic and technological globalisation and the rules of the World Trade Organization, the International Monetary Fund, the World Bank, stock markets, currency exchange as well as central banks. Since the 1980s and the waves of global deregulation and privatisation unleashed by Britain's Margaret Thatcher and US President Ronald Reagan, central banks lobbied for freedom from political control - even by democratically elected governments. Even Britain's labour government under Tony Blair conceded this 
autonomy to the Bank of England. In the USA, Altman's (2004) analysis of the agenda of the neoconservatives, Neoconomy: George Bush's Revolutionary Gamble with America's Future and Batra's (2005) Greenspan's Fraud reveal their intentions to dismantle the 'New Deal' of Franklin D. Roosevelt, including Social Security, Medicare, laws protecting employee rights, union organising, abortion, welfare and other legislation of the past 60 years.

This quiet 'coup' achieved by central bankers and their advocates among the economics profession is illustrative of the methods of neoconservatives, such as those currently dominant in the USA. Yet, the failures of these economic models in achieving their targets of non-inflationary economic growth and fuller employment is evident in the recent history of financial crises, booms, busts, bubbles, unrepayable debt and unemployment. The policy drumbeats of economists and market players supported central banks. They were buttressed by their claims that economics with its increasing use of mathematical models, had matured into a science, matching the feats of natural sciences since Newton and Darwin in discovering the laws of nature. Economists' theories from Smith's 'invisible hand' to Vilfredo Pareto's 'optimality' were elevated from theories to the status of scientific principles. Many debates over categories and indicators derived from such theories involve basic questions of causality. For example, why is education a 'cost' not an 'investment'? (Henderson, 2004b).

In 1969, the Central Bank of Sweden put up \$US1 million to create a prize to confer scientific status and legitimacy on the academic discipline and widespread policy advocacy of the economics profession. Thus, the Bank of Sweden named its economics prize 'in memory of Alfred Nobel' and lobbied this designation onto the Nobel Prize Committee. As his descendant, Peter Nobel, put it, "The Bank of Sweden, like a cuckoo, laid its egg in the nest of another very decent bird, infringing on the name and trademark of Nobel". Since 1969, most of the Bank of Sweden Prizes in Economic Science has been awarded to US economists espousing the Chicago School policies of laissez faire 'free markets' typical of its most prominent prizewinner Milton Friedman (who is often erroneously described as a 'Nobel laureate'). Peter Nobel added, "These economists use models to speculate in stock markets and options - the very opposite of the humanitarian purposes of Alfred Nobel". ${ }^{6}$ Chicago School doctrine holds that if individuals and private business make money then this process will eventually 'lift all boats' in a rising tide of prosperity - thus confusing money with wealth - a much broader concept. While controversies have often surrounded Nobel awards, arguably the Bank of Sweden prize should be properly named, since economics is central to public policies in all countries and multilateral agencies. The prizes for peace and literature rarely impact the daily lives of billions of people. Some prizes in peace and science have been controversial and too often encouraged military research driven by corporate contractors, profit, personal greed and ego-gratification. As a scientific advisor to the US Congress from 1974-1980, I found 'intellectual mercenaries' flourish in business, government and academia.

In December 2004, many scientists revolted, including members of the Nobel Committee and Peter Nobel himself, and demanded that the Bank of Sweden's economics prize either be properly labelled and delinked from the other Nobel prizes - or abolished. The reason for this sudden outburst, which had been brewing for some time, was the awarding of the economics prize to two more Chicago School economists Edward C. Prescott and Finn E. Kydland for their 1977 paper purporting to prove by use of a mathematical model, that central banks should be freed from the control of politicians - even those elected in democracies. The mathematicians pounced - pointing 
to the many misuses of their models by Prescott and Kydland and other economists to 'dress up' their questionable theories and unscientific assumptions (Dagens Nyheter, Stockholm, 10 December 2004).

As this news spread around the world (InterPress Service, January 2005, Henderson, 2005) the usual heralding of the new economics prizewinners in the mainstream financial press was strangely muted. Editors and spokespersons for market fundamentalism fell quiet in their citing of their favourite policies as backed by some 'Nobel laureate' in economics. Yet economics is an honourable profession, like law, medicine, engineering, architecture and other such applications of knowledge. Lawyers are known as advocates. Economists have always been advocates of various government policies, regulations or deregulation, and of the interests of their clients (most often bankers, financial firms and corporations in general). These advocates, whether lawyers, economists or lobbyists, have legitimate roles in policy-making. Transparency requires policy-making so that the public is fully informed - and the issues are argued honestly.

The globalisation of finance and technology, the spread of privatisation and deregulated markets have produced a range of unanticipated consequences. For example, today's Global Information Age has already become the Age of Truth - where careless corporate actions can destroy a global brand in real- time. Business leaders worldwide have responded by embracing the idea of good corporate citizenship, both at home and globally. Two thousand companies (including some 600 in Brasil) have signed on to the ten principles of Global Corporate Citizenship of the Global Compact, launched by the United Nations in 2000, covering human rights, workplace safety, justice and ILO standards, as well as the environment and anti-corruption. Civic groups worldwide now monitor all the companies which have engaged with the Global Compact, to see if they are walking their talk. Backsliders are publicly shown on hundreds of websites. The World Social Forum has successfully linked hundreds of thousands of civic activists and organisations and made the beautiful city of Porto Alegre a mecca of innovative thought. My TV series 'Ethical Markets' on US public broadcasting stations benchmarks higher standards, corporate ethical performance and socially-responsible investing worldwide. ${ }^{7}$ Contrary to The Economist's editorial scepticism about such corporate social responsibility, ${ }^{8} 77 \%$ of CEOs of major corporations surveyed by KPMG and the World Economic Forum in 2005 said that such higher ethical behaviour was "vital to profitability'.

Capitalism's great proponent, Adam Smith argued that markets could only work efficiently if all buyers and sellers had equal power and information and no market transactions harmed others. Smith might hardly recognise today's evolution of global markets or companies moving toward social and environmental responsibility. Similarly, such changes in corporate behaviour have been driven by trillions of pension funds' dollars and millions of investors who care about their children's future and the state of our planet. Students and prospective employees also ask about companies' performance on human rights and the environment, while new auditing standards of the Global Reporting Initiative (GRI) prescribed 'triple bottom line' accounting for people, profit and environment. Six hundred global corporations now comply with GRI accounting in their Annual Reports. ${ }^{9}$ (Figure 3) Sustainability has become a buzzword and even Wall Street's venerable Dow-Jones now has its Sustainability Group Index. The surprise to economists, mainstream financial players and media is that these new indices: London's FTSE4Good, the US Calvert Social Index and Domini Social 400 Index, as well as 
Brasil's New BOVESPA, regularly outperform the mainstream Dow-Jones and Standard and Poors 500. ${ }^{7}$ Are we witnessing an evolution of human collective behaviour toward moral sentiments and altruism? Or is cooperation for the common good now a condition of our survival? I submit that both are involved.

Figure 3 Ceres global reporting initiative

\section{CERES GLOBAL REPORTING INITIATIVE ACCOUNTING FOR SUSTAINABILITY}

Sample Dimensions and Criteria:
\begin{tabular}{|l|l|l|l|}
\hline $\begin{array}{l}\text { COMPANY } \\
\text { PERFORMANCE }\end{array}$ & ECONOMIC & SOCLAL & ENVIRONMENTAL \\
\hline Diversity & Diversification & Employee Diversity & $\begin{array}{l}\text { Resource - Use } \\
\text { (Renewable or Non) }\end{array}$ \\
\hline Added Value & $\begin{array}{l}\text { Retumn on Capital } \\
\text { Employed }\end{array}$ & $\begin{array}{l}\text { Intangible Values } \\
\text { Knowledge }\end{array}$ & Re-using "Wastes" \\
\hline Productivity & Profit Margins & $\begin{array}{l}\text { Employee and } \\
\text { Customer Retention } \\
\text { Rates }\end{array}$ & $\begin{array}{l}\text { Resource-Use } \\
\text { Efficiency }\end{array}$ \\
\hline Integrity & $\begin{array}{l}\text { Disclosure } \\
\text { Political } \\
\text { Contributions }\end{array}$ & Complaints Lawsuits & $\begin{array}{l}\text { Environmental } \\
\text { Management }\end{array}$ \\
\hline Health & $\begin{array}{l}\text { Rating Agencies } \\
\text { Reports }\end{array}$ & $\begin{array}{l}\text { Employee Injury } \\
\text { Eenefits }\end{array}$ & $\begin{array}{l}\text { Health Risks of } \\
\text { Products, Facilities }\end{array}$ \\
\hline Development & Imovation & Employee Education & $\begin{array}{l}\text { Environmental } \\
\text { Techologies }\end{array}$ \\
\hline
\end{tabular}

We are also entering the Age of Light (See Figure 4, The Age of Light). As we humans shape this current global stage in our development, our new awareness of our beautiful planetary home is calling forth an expanded identity, which I explored with Japanese Buddhist leader, Daisaku Ikeda of Soka Gakkai (with some 20 million members worldwide) in our 'Planetary Citizenship'. (Henderson and Ikeda, 2004) (See Figure 5, Toward Planetary Citizenship). This larger identity enfolds and gives deeper meaning to our identity with our family, our community and companies, and the country of our birth. We are enriched by the unique expressions of so many other cultures in our world. We savour their art, dance, music, literature and especially their cuisine! This human mutual appreciation for diversity is the starting point for planetary citizenship and the necessary transition to global sustainability, as the online global debates of the Global Transition Initiative illustrate. ${ }^{10}$ Fundamentally, we humans have three basic resources at our disposal for this transition - information, matter and energy (See Figure 6, Three Modes of Resource Use). Of these, information is primary, since the quality of information drives our use of matter and energy. 
Figure 4 The age of light

\section{The Age of Light}

Emerging Lightwave Technologies (Photonics)
Fiber optics, Optical scanners, Lasers, Holography
Solar technologies
Optical computers, Multiprocessor, parallel
computers and neural net computers,
Imaging technologies
Biotechnologies
Gene machine, DNA sequencers, Tagging and
tracking chemicals and genes, Nano technologies
Photons sunnight falling on the Earth supply enough energy in 10 minutes to put our entire six billion population in orbitt

Figure 5 Toward planetary citizenship

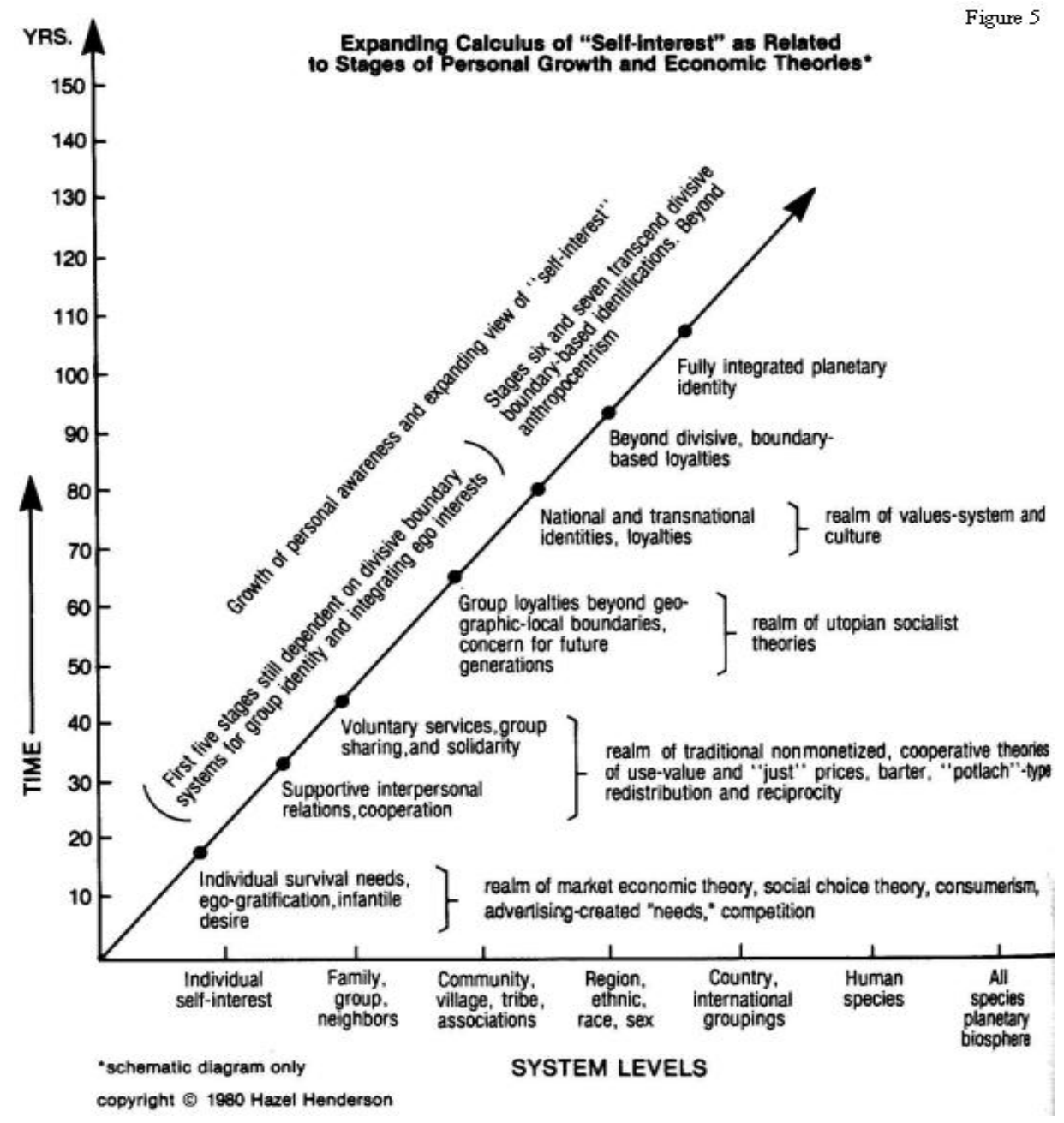


Figure 6 Three modes of resource use

\section{MODES OF RESOURCE-USE IN NATIONAL DEVELOPMENT}

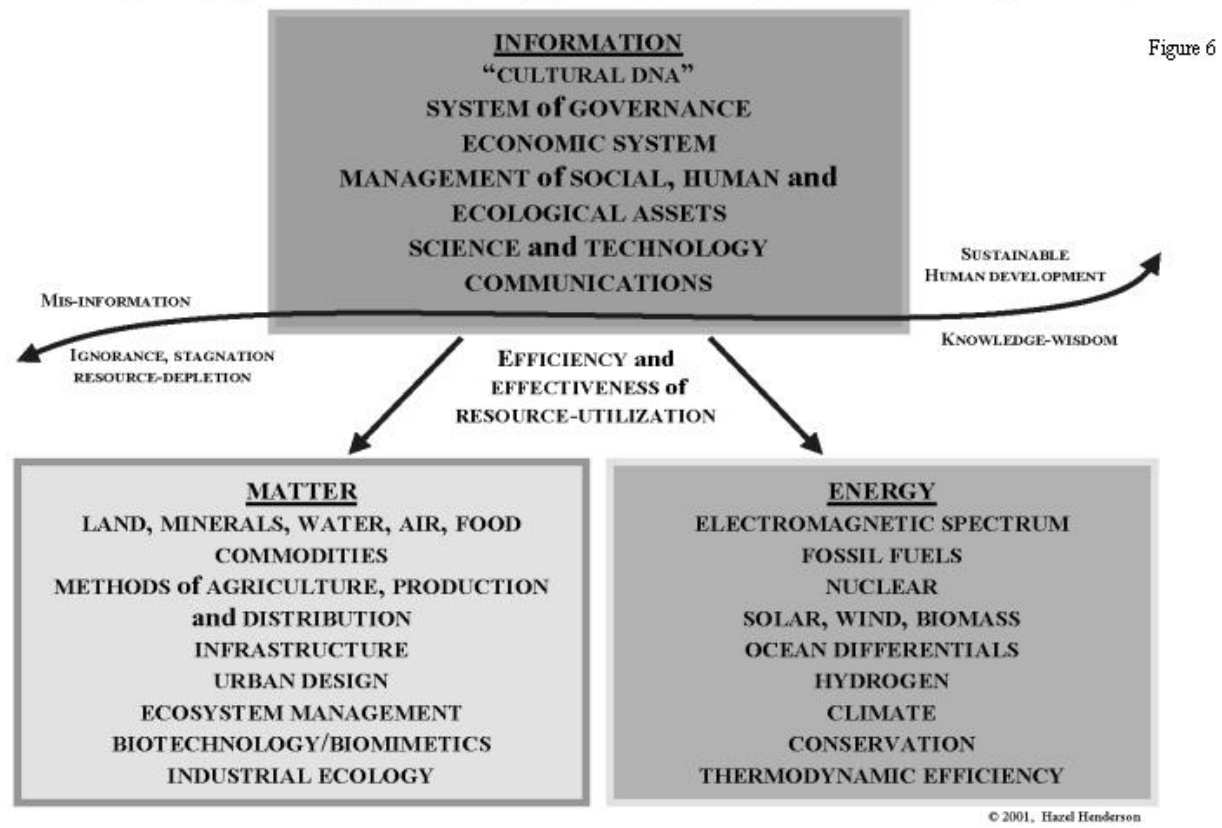

The history of the social innovation of markets is instructive, since they are now evolving rapidly. Markets of course, were created by humans, not by any deity. Adam Smith's 'invisible hand' was in reality our own human invention, as recognised by historians of science. (Nadeau and Kafatos, 1999) Yet, this belief in an 'invisible hand' persists in many economic textbooks - even today, buttressing neoconservative agendas expressed by such philosophers as Friedrich Hayek and Ayn Rand and her aficionados including Alan Greenspan, Chair of the US Federal Reserve. Not only are independent central bank policies obscure and driven by often obsolete general equilibrium models, central bankers are also politically motivated. For example, Italy's independent central bank president, Fazio is accused of cronyism, condoning fraud in the Parmalat scandal and disregard for ethical standards. ${ }^{11}$

The organisation of markets by the British Parliament three centuries ago fostered the rapid evolution of industrialism (Polanyi, 1945). These early markets described by Smith sparked many innovations. The British laws that legitimised markets and protected property rights led to a revolution of individual entrepreneurship, creativity and innovation, which spread across the Atlantic Ocean and Europe. This 300 year-old wave of industrialism spread around the world and today is still changing Japan, China, India and reaching the other ancient cultures of Southeast Asia from Vietnam and Cambodia to the Islands of Polynesia (Landes, 1998). Yet, industrialism must be reshaped because it is socially and environmentally unsustainable. 
The early markets of the Industrial Revolution and their business leaders created the infrastructure platforms of concrete, steel, electricity, mechanised production, shipping, roads and ports that still undergird today's societies. But the market freedoms provided by social legislation limiting companies' liabilities, enforcing property rights, upholding their patents to their inventions, also brought great harm to less fortunate, vulnerable members of society. Who can forget the history book pictures of those early sweatshops: the children chained to spinning machines in textile factories, the women dragging carts of coal on their hands and knees in Britain's coal mines? Industrialism's goal was labour-saving via investments in technology. Machinery, property rights and the Enclosure Laws drove peasants and small farmers off their ancestral common land and into factories. Then, as factories automated their production lines, workers moved into service sectors. Today, services are being automated. Full-employment promises fall short and unemployment remains an ironic result of industrialism. Today, economists are admitting that the flip side of their model of 'labour productivity' is more unemployment. The social costs of disruptive technological change are borne by employees unless governments and taxpayers cushion unemployment and provide retraining. Yet, as Chinese analysts rightly observe, markets are good servants but bad masters. If prices correctly include all external costs they can guide resource allocation decisions efficiently. The other main feedback from individuals to decision-centres, votes, must be uncorrupted by money, rigged elections, jerry-mandering and other distortions.

In every country where industrialism took hold, the 'tortoise' of social innovation lagged behind the 'hare' of technological innovation. The history of the Industrial Revolution with all its good and bad news has included the lagging response of social rules to distribute the fruits of mechanised production and steer technological development and regulations to ameliorate its social costs and environmental damage. The very notion of an 'invisible hand' inhibited broader views and visions of how economic systems could be steered to foster the common good, shared prosperity and protect nature's wealth. In the USA, lawyer Louis O. Kelso and philosopher Mortimer Adler challenged economists' panglossian model of 'frictionless' technological change. Kelso recognised that if a machine took over a worker's job, then the worker would need to own a piece of that machine. Employee Stock Ownership Plans (ESOPs) now exist in 11000 US employee-owned companies (Rosen et al., 2005). A few industrialists evolved from their single-minded accumulation of money and material goods - into philanthropists promoting wider access to education, health and other global public goods.

The economist, Schumpeter (1942/1947) best described these processes of 'creative destruction' that also drove this greatest period of technological innovation in human history. The Information Age superseded industrialism itself in the mid-20th century. This new wave of innovation has produced all the good and bad news of today's globalisation of markets and technology. In my Politics of the Solar Age (1981/1986), I documented the ideological biases of neo-classical economics and the unreality of many of the inaccurate assumptions underlying even today's economics textbooks. The new chorus of scientists in physics, mathematics, neurosciences and ecology joined their Swedish colleagues in calling for the Bank of Sweden Prize in Economics to be broadened, properly labelled and disassociated from the Nobel Prizes - or simply abolished. The objections from scientists who study the natural world and whose research findings are therefore subject to verification or refutation included scores of ecologists, 
biologists, natural resource experts, engineers and thermodynamicists. I documented their critiques of economics, building on the 1971 classic by Georgescu-Roegen, The Entropy Law and the Economic Process, which I reviewed in the Harvard Business Review (1971).

Other scientists including physicist, Professor Dr. Hans Peter Durr of Germany's famed Max Planck Institute agree that economics is not a science. Durr says "economics is not even bad science because its core assumptions are incorrect". I had previously asked Professor Durr "how could such a scandalous misuse of other sciences have continued unchallenged for over 40 years?" Durr replied that academic etiquette usually restrained scholars from other fields from straying into other disciplines, especially with such criticisms. Austrian physicist, systems theorist, author of The Web of Life, Fritjof Capra asserts that "The dimension of meaning, purpose, values and conflicts is critical to social reality. Any model of social organisation that does not include this critical dimension is inadequate. Unfortunately, this is true for most theoretical models in economics today" (Henderson, 2004a).

Even the growth of hybrid professions - so-called ecological economics, natural resource economics and others, cannot escape economics' fundamental errors. Many critics liken its postulates to religious beliefs. For example, I showed that economics' Pareto Optimality 'principle' ignored prior distribution of wealth, power and information - and could lead to unfair social outcomes. Dressing up such concepts in fancy mathematics tends to disguise their underlying ideologies. Professor Nadeau (2003), a distinguished historian of science at George Mason University in the USA examined such flaws in economics in his recent books, and challenged economics faculty to engage in public debates.

The temptation to mathematise concepts and faulty assumptions in economics is understandable, because it obscures these value-laden biases. This conceals public issues as too 'technical' for the public or even legislators to understand. Thus, economists can gain influence with central banks and other wealthy and powerful institutions in society. Neither have economists been held to the same standards of accountability as other professions. If a doctor makes a patient sick, a malpractice suit can be filed. Economists' bad advice can make whole countries sick - with impunity, as, for example, IMF economists' advice worsened Indonesia's economic woes in 1997. Today, economists from the IMF and central banks to those serving financial firms all bemoan the trend toward spending rather than saving. They refuse to acknowledge that this behaviour is shaped by advertising, credit cards and the constant barrage of consumerism on global mass media. ${ }^{12}$

Neuroscientists, biochemists and those studying the role of hormones, as well as psychologists, anthropologists, behavioural scientists and evolutionary biologists are now dealing death blows to economics' most enduring error. This lies in its model of 'human nature' as the 'rational economic man' who competes against all others to maximise his own self-interest. This fear and scarcity-based model is that of the early reptilian brain and the territoriality of our primitive past. Neuroscientist Zak at Claremont University, California, has linked trust, which enables humans to bond and cooperate and is crucial to markets, to the reproductive hormone, oxytocin.

Indeed, we now know from brain science why people are susceptible to behaviour change via mass media, advertising and other forms of persuasion and lures to instant gratification. Opportunistic economists are now teaming up with brain researchers using Magnetic Resonance Imaging (MRIs) to explore how the 'reptilian' portions of the 
human brain (associated with the limbic system) are susceptible to irrational urges, instant gratification and short-sightedness. The discovery of 'mirror' brain cells enabling humans to empathise with each other - also accounts for human suggestibility and the power of persuasion in mass media and advertising. Now that economists' competitive self-interest models of human behaviour are under attack by such brain research, this field is being colonised as 'neuro economics' or 'behavioural economics' in the same way that economists captured other disciplines as 'ecological economics' and 'environmental economics'. This tendency to colonise other disciplines with false claims of universality was due to the power and financial advantages of economists as apologists for the powerful interests of business and finance.

It remained for honest reporters to explain: in Coy (2005) and Fox (2005). Coy and Fox point out that humans are always 'of two minds' about the signals in their lives and environments. They shift back and forth between their pre-frontal cortex (the seat of rational decision-making) and their reptilian, limbic brains. As yet, few have focused on the implications of this new brain research for the crucial role and responsibility of the advertising and commercial media industries. Over $\$ 400$ billion is spent annually on advertising to override our rational pre-frontal cortex and its longer-term decisions 'to save for a rainy day' and tempt us to run up credit card debts to buy goods on impulse - through sophisticated manipulation of our senses and limbic brains. Advertising in the USA is a pretax cost for companies - to promote mass consumption. Today, mass consumption of goods as an engine of economic growth is unsustainable (Henderson and Kay, 1998). ${ }^{13}$

The critique of economics by mathematicians is that people don't behave like atoms, golf balls or guinea pigs. Unlike the economists' 'rational economic man' people are often irrational and their motivations are complex, with many, especially women, enjoying caring, sharing and cooperating often as unpaid volunteers. Chaos theorist Ralph Abraham believes that economics may one day become a science. Abraham is researching with the Santa Fe Institute the new mathematics employed by some economists, by programming 'agents' in computer models that are supposed to mimic human behaviour. Prof. Abraham adds, "The so-called 'Nobel Memorial' prize in economics should be broadened in line with the full spectrum of social sciences to which it belongs and it should be distanced from the Nobel awards, like the Fields Medals in mathematics". Meanwhile, Peter Nobel maintains that economics is not a science. Riane Eisler, systems scientist and author of the bestseller, The Chalice and the Blade, agrees. The agent-based computerised efforts to make economics more scientific may pay off in the future. One recent model 'Sugarscape' funded by gullible foundations, simply recreated poverty gaps and trade wars. Clearly, if they had programmed half of their 'agents' with the behaviour females so often exhibit (by choice, or involuntarily in patriarchal societies) they might have produced different results. Economics is patriarchal to its core, which accounts for the rise of feminist economics (Henderson, 2005).

Today, all economies are still mixtures of public and private sectors, two sides of the same coin with markets created by human rules and laws - a major social innovation. The two top layers of the 'cake' of total productivity, the private and public sectors, rest on two lower layers ignored by economists: the Love Economy of unpaid work and Nature's Productivity (See Figure 7, Total Productive System of an Industrial Society, Foresight). Mass communications and the Internet enlarged the new Third Sector: the citizen non-profit groups, charities and foundations of global civic society. The World 
Social Forum, launched in Porto Alegre, in 2000, has focused the global debate about new paths to sustainable human development. The 'cultural DNA' of societies always determines the size and scope of public, private and civic society sectors: based on their unique history, values, goals and beliefs that energise their people. The one-size-fits-all economic theories of development, such as the 'Washington Consensus' have been discredited as they encountered the realities of the unpaid Love Economy, informal sectors, diverse cultures, topography, climate, agriculture and the basic productivity of ecosystems.

Figure 7 Total productive system of an industrial society, foresight

\section{Total Productive System of an Industrial Society (Layer Cake With Icing)}

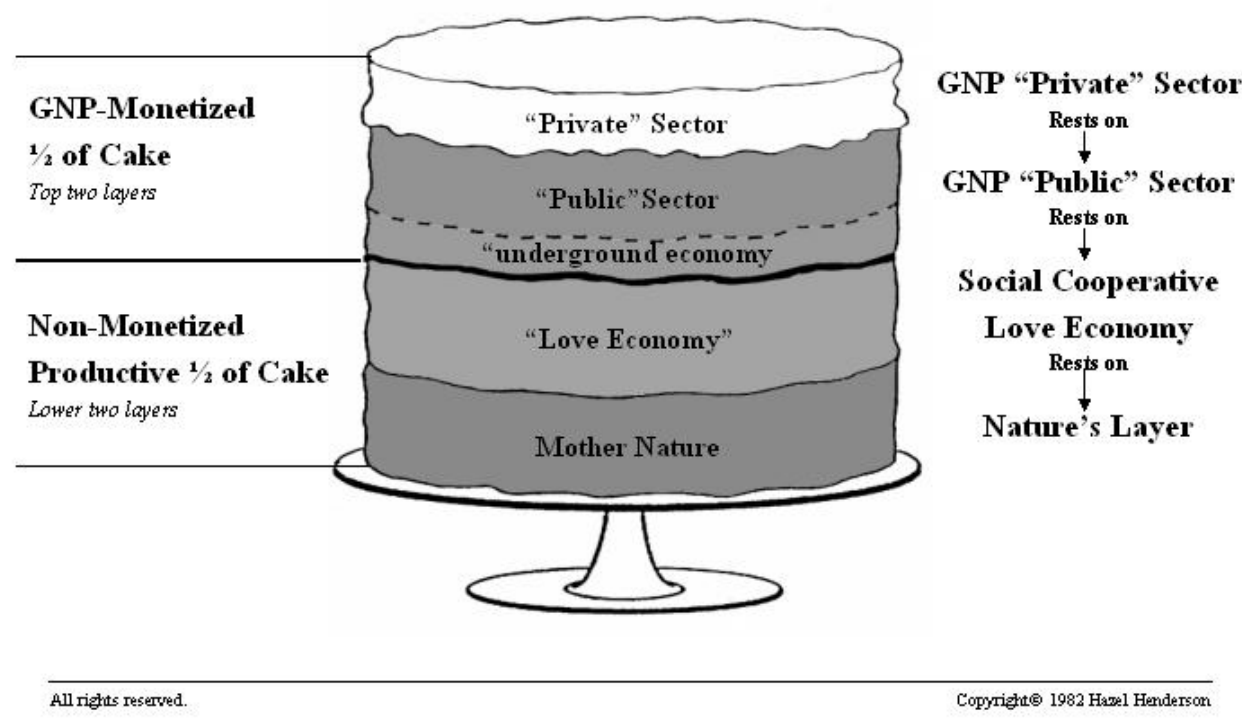

Cultural DNA still drives development in all societies - even though these human, social and cultural assets (and sometimes liabilities) are overlooked in economic textbooks, theories and the statistics they generate. Economic models still based on the Newtonian 'clockwork' ideas of general equilibrium are now over a hundred years out of date. Thus, they are also blind even to the dynamic change and technological evolution engendered by the very markets and industrialism on which economists claim to focus and interpret. These dynamic changes are now mapped by other disciplines: chaos theory, system dynamics, physical and behavioural sciences and game theory. Today, economists are beginning to focus on this colossal error and awaking to the fact that general equilibrium economic models cannot be used to guide macro-economic policy in rapidly evolving technological societies. Chaos models, such as those created by two 'Nobel Memorial' prizewinning economists for the collapsed hedge fund, Long Term Capital Management, as well as others used by firms trying to beat stock markets fail because they rely too much on historic trends and patterns. 
Economists' colonising tendencies expanded to 'capture for our profession' (as a UK-based economics society put it) (Henderson, 1996) the issues of global warming and climate change. Economists trump other disciplines in academia because their departments and business schools receive the lion's share of funds, research contracts, power and prestige. Economics is politics in disguise. Cost-benefit analysis or a carefully crafted economic impact statement can squelch any government reform or new social or environmental initiative. Such analyses emphasise the costs of change to existing interests, while ignoring or downplaying the current costs of the status quo on other actors, the environment or future generations. Examples include the 2005 energy, transportation and drug subsidy laws in the USA. Cost-benefit analyses fail to estimate the future benefits of alternative policies and average out costs and benefits so as to obscure who are the winners and who the losers of a proposed policy. All this confuses the general public into believing that the issues are 'technical' rather than political, as documented in Priceless, which analysed recent policies in the USA (Ackerman and Heinzerling, 2004).

Today, the chinks in economists' armour are becoming widely evident - including the game of pre-empting the work in other disciplines. Psychologists won recent Bank of Sweden Memorial Prizes in Economics for challenging simplistic economic models of human behaviour. Even Harvard University may soon allow a new course in its economics department that challenges the orthodoxies still undergirding the policies of the IMF and the decisions of Wall Street and the world's bourses. A few economists borrowing from psychologists and real world observation now admit that we humans are not always competitively maximising our own self-interest - the standard economic view of homo economicus. Many people enjoy giving as well as receiving, caring about what kind of world we are leaving our children - 'irrational' behaviour to an economist. No wonder economics is called 'dismal'. This re-think undermines orthodoxy in such major policy areas as free trade, taxes, school vouchers, as well as globalisation and the environment.

Hotz (2005) describes a recent experiment at Baylor College of Medicine in Houston, Texas where two women were observed with the use of a $\$ 2.5$ million brain scanner, as they interacted in a game involving financial and investing behaviour. The brain researcher's goal was to test and hopefully discover the secret of trust, the crucial human behaviour that makes markets possible - and the variable missing from the mathematics used by economists in their models. Neuro Scientist Paul Glimcher of New York University explained that "we have started looking for pieces of economic theory in the brain." After monitoring the many moves between the two young women, it turned out that, contrary to economic theory and many game theorists, these two female players trusted each other. Economics and traditional game theory predict that lack of trust on the part of both players would cause both to lose (the Prisoner's Dilemma). The outcome of the women's game was that both won. Such optimal outcomes are termed 'win-win' games as opposed to the 'win-lose' games of economic theory and the 'lose-lose' outcome of the Prisoner's Dilemma game.

This outcome also challenges game theorist John Nash's famous equilibrium, for which he won a Bank of Sweden Prize in Economics, and which 'predicts' that in economic transactions between strangers predicting each other's responses - the optimal level of trust is zero. Economics is based on patriarchal values - devaluing the work of women in child rearing, caring for the old, community volunteering as 'uneconomic' in 
GNP. Economics did not predict the rise of socially responsible investing (now at $\$ 2.2$ trillion in the USA alone) ${ }^{14}$ and textbooks still imply that trusting, caring, sharing, volunteering and cooperating are irrational unless self-serving.

MIT-trained economist, Perkins (2004), author of Confessions of an Economic Hit Man documents the misuse of economics to overestimate GDP growth projections to justify the huge World Bank and IMF loans to many developing countries in the 1980s, which ensnared them into unrepayable debt. The best-known economists in the USA are admitting these and other errors, including Paul Krugman, Joseph Stiglitz and Jeffrey Sachs. Unsung women economists revealed the patriarchal bias of economic theories and led the way in pinpointing these and other errors. They devised more realistic models - from Sweden's Alva Myrdal, India's Devaki Jain, Denmark's Esther Boserup, to Argentina's Graciela Chichilnisky, Brasil's Aspasia Camargo and futurist Rosa Alegria, Germany's Inge Kaul, New Zealand's Marilyn Waring, myself and many others in the US and other countries.

Statistical revisions, including those to overhaul GNP and GDP national accounts were pledged by 170 governments at the Rio de Janeiro Earth Summit in 1992. (See Figure 8, Gross National Product Problems). They were also recommended by the largest-ever global convening of statisticians of sustainable development and Quality of Life (ICONS) in Curitiba, Brasil October 2003 (Henderson, 2003b). Such statisticians have also repeatedly recommended that GNP and GDP record national assets: the value of public infrastructure investments in roads, public health facilities, sewage treatment, ports, airports, schools and universities that underpin the productivity of modern economies. In too many countries, these asset accounts, which properly balance the public debts undertaken to construct such vital infrastructure - are not recorded. Such public works, buildings and facilities are immensely valuable and should be amortised over their lifetime of use - often over a hundred years. Try running a company like this, where your balance sheet could not include the value of your factories and capital assets. The USA made some of these needed corrections in January 1996 and these 'stroke of the pen' corrections accounted for one third of the budget surplus of the Clinton administration. Canada followed suit in 1999 and went from a deficit to a $\$ 50$ billion budget surplus (Henderson, 1999). The investments called for in the Millennium Development Goals, the Monterrey Consensus and other proposals, such as the Global Marshall Plan, must be properly accounted as assets, since they will also produce dividends for societies as they transition to sustainability.

Today, in our Information Age, we acknowledge the value of investments in research and development, management education and employee training programmes. Accountants are learning to account for intangible assets, goodwill, brands and other reputational risks and benefits. (Allee, 2003) Risk-analysis models, such as those of Innovest Strategic Value Advisors, Inc. (New York, London, Toronto, Hong Kong) now calculate social and environmental risks overhanging a company's balance sheet - which if not recorded, can be overlooked and lead to sudden loss of shareholder value. Multi-billion dollar US public pension funds now require companies in their portfolios to disclose their plans to mitigate risks of climate change. Similar disclosures are mandatory in the European Union. Another area is corporate advertising, which is coming under increasing public criticism. I founded the non-profit EthicMark Institute, which will be based at Case Western University at the Center for Business As Agent of 
World Benefit, founded by David Cooperrider and Judy Rodgers. The EthicMark Institute will recognise advertising campaigns that inspire and enhance the human spirit with the 'EthicMark' certification.

Figure 8 Gross national product problems

\section{Gross National Product Problems}

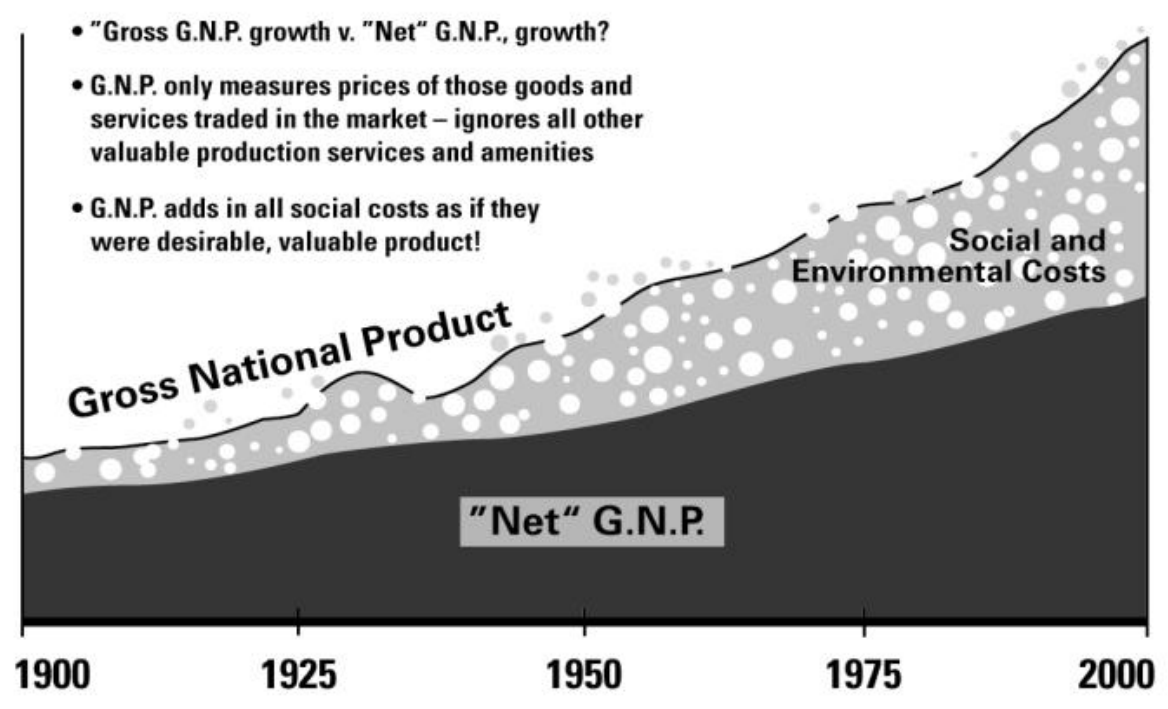

C1978 Hazel Henderson • Source: Creating Alternative Futures, 1978, 1996, Kumarian Press, West Hartford, CT, USA

The World Bank was catching up with all these statistical innovations - beyond macroeconomic models to multidisciplinary systems approaches - using all the multiple metrics beyond money to map these diverse aspects of human development and progress. This progress may easily revert to the neoconservative agenda and laissez faire models of the past. I and my partner, The Calvert Group of socially responsible mutual funds use the multidiscipline approach in our Calvert-Henderson Quality of Life Indicators, which are updated regularly at www.calvert-henderson.com (Figure 9). The World Bank staffing was also going multidisciplinary - replacing some of its macroeconomists with sociologists, anthropologists, epidemiologists, educators - and even civic society representatives. Under neoconservative management of President Wolfowitz, these policy innovations may be reversed. In its 1995, report on the Wealth of Nations, the Bank acknowledged that $60 \%$ of this wealth is comprised of human capital and $20 \%$ ecological capital. Financial and built capital (factories and monetary assets) represented only $20 \%$. For 50 years the Bank focused most of its attention on 'economic' growth of this $20 \%$ of countries' wealth. Now, the Bank is shifting its focus to that $60 \%$ of human capital with more health and education investments - recently citing the education of girls as a country's best investment. 
Figure 9 Calvert-Henderson Quality of Life Indicators

\section{CALVERT-Henderson QUALITY OF LIFE INDICATORS}

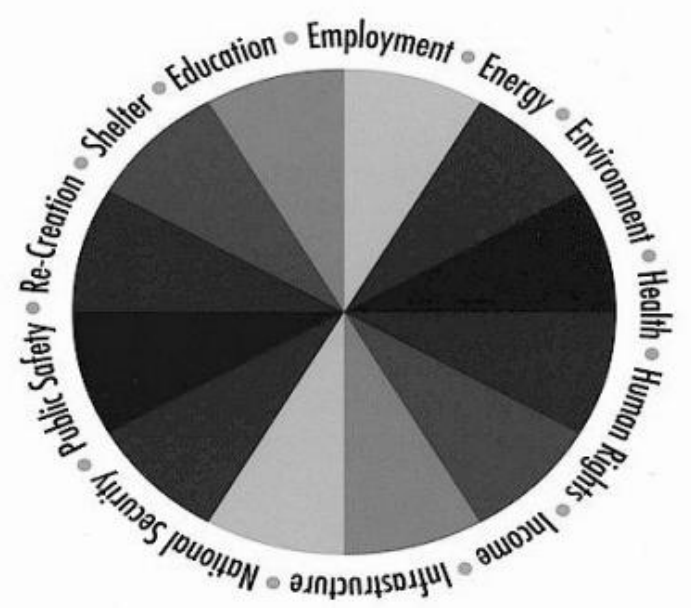

A NEW TOOL FOR ASSESSING NATIONAL TRENDS

Yet the Bank has not, so far, campaigned to add even public asset accounts to GNP/GDP. Neither the Bank nor the IMF require the addition of asset accounts, even for infrastructure assets, let alone for education and health - the most vital investments to maintain that $60 \%$ of the human capital comprising the wealth of nations. These accounting corrections will shift statistical focus to longer-term and sustainable investments. Brasil is helping the IMF to correct its GNP/GDP accounting. In April 2004, the IMF agreed with Brasil that its vital backlog of infrastructure investments in rapidly growing urban areas for basic sanitation and other public facilities should not be accounted for in ways that would increase the public debt. However, the IMF only agreed to the correct accounting for these public assets as a 'pilot project,' an intellectually absurd position. The IMF is still resisting adoption of these corrections due to pressure from Wall Street bond holders, banks and other financial special interests that benefit from high interest rates. This issue can be advanced at the WTO by the Group of 20 and the G-77. The recent appointment by President Bush of neoconservative John Bolton to serve as US Ambassador to the UN may impede such overhauls of GNP/GDP national accounts. 
I and other critics of the IMF's many mistakes over the past decades are now calling for the permanent overhaul of their GNP/GDP and all other macro-economic models. The IMF should not only set up proper accrual accounting of assets for all investments in public infrastructure - but should re-categorise education and public health from 'consumption' to 'investment' in human capital. The World Bank and the UN System of National Accounts (UNSNA) should make similar corrections and add nations' public investments in education and public health to these asset accounts and amortise them over 20 years - the time it takes to raise a child to a healthy, well educated, productive adult. It is these accounting corrections that can reveal the opportunities for long-term financial and social returns in the Millennium Development Goals, as Sachs (2005) shows in The End of Poverty.

As these statistical innovations reflect the technological changes in our information-based societies, and are reported in mass media, citizens in all democratic societies will align with these evolving values. New business school curricula now cover all these new issues and indicators. Pre-eminent is Brasil's Amana-Key Desinvolvimento and Educacao in Sao Paulo. Others include, World Presidio College in San Francisco, which offers an MBA in sustainable business and the Center for Business as Agent of World Benefit at Case Western University, Cleveland, Ohio. Citizens will understand and place education and self-development as the best investment individuals, companies and societies can make in a better future for all. Even neoconservative economics recognises that education is a 'public good', a 'positive externality' in economic jargon, i.e., activities that individuals and private business are unlikely to fund adequately since they cannot capture the full returns to such private investments. Economists still need to clarify the difference between markets ruled by competition and commons - which require cooperative rules (Figure 10, Differing Views of Markets and Commons), as I argued (Henderson, 1995).

Figure 10 Differing views of markets and commons

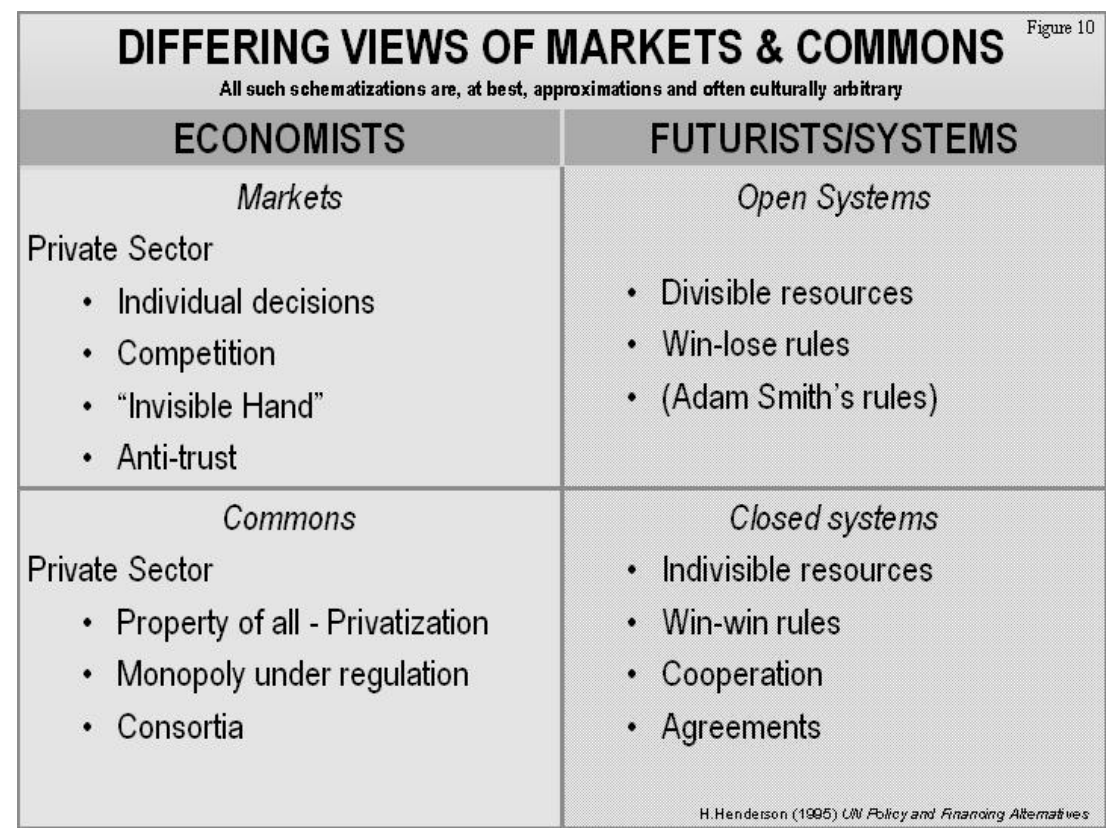


Educators and public health professionals and the majority of citizens can support adequate taxes so crucial to their children's futures. In light of the new brain research, the current practices in US public schools of commercial sponsorship of TV news, sports and events, product advertising, junk food vending machines and curricula prepared by corporate PR departments - all to supplement budgets - may be ruled illegal. Research shows that children and adolescents have not yet developed forebrain capabilities to override such influences. Teachers can be better paid and schools will no longer have to fight in annual government budgeting with other expenditures for needed police, fire protection and other public services and in national budgets, even military weapons.

As all such new scorecards of real wealth and human progress are implemented, societies and companies can steer themselves on sounder paths toward order and prosperity. Companies can hire firms like Truecost to identify avoided costs in full-cost pricing, life-cycle costing and like Innovest to perform social and environmental risk-analyses - while fully crediting their intangible assets and investments in R\&D. For big companies, these changes are less arduous than for smaller companies. So it is important to also recognise the efforts of small and medium-size enterprises and encourage their progress.

The new GNP/GDP asset accounts will end today's egregious overstating of public debts and the excuses it offered for excessive interest rates, sovereign bond yields and currency speculation. Developing countries in the HIPIC group are already being relieved of unrepayable, often odious debt under formulas agreed at the July 2005 G-8 Summit in Scotland. Former IMF Chief Economist, Kenneth Rogoff, suggested many reforms in his article in The Economist, 24 July 2004. I moderated five TV debates on 'Reforming International Finance' between Rogoff; John B. Perkins, author of best seller Confessions of an Economic Hitman; Sakiko Fukuda-Parr, Lead Author of the UN's Human Development Report. ${ }^{15}$ Even before the G-8 Summit, the IMF's new president, Rodrigo Rato accepted the need to change many of its socially disastrous policies and to write off more unrepayable debt - largely due to global civic society and public opinion.

In this new century, long-held ideas are changing. The European Union is a new model of integration of formerly warring countries. Despite the 'No' votes in France and Holland over the proposed EU Constitution and recent budget squabbles - negotiation, cooperation and multilateral agreements are the way forward. The wars in Afghanistan and Iraq have revealed the many problems that even politicians and military leaders now admit, require diplomatic solutions. New approaches to terrorism now favour funding education and building schools in countries where poor parents have no choice but to send their children to fundamentalist 'madrassahs' where they are taught the ways of 'jihad' and suicidal 'martyrdom' to kill others in the name of God. Societies that pandered excessively to individual immigrants' rights to retain their own culture and language (multiculturalism) are re-balancing toward the needs of societies for inclusive, shared values, languages and the 'melting pot'. Meanwhile, the search for balance between the rights of individuals and society continues.

In our age of weapons of mass destruction, wars are the most dangerous and ineffective options. We see already in our 21 st century that the new weapons of choice are currencies, as well as better diplomacy, intelligence and widely shared information. Investments geared toward the Global Marshall Plan can help guide the re-prioritising needed to steer societies toward equitable resource-use and reduction of conflicts (Radermacher, 2004). Insurance policies for peacekeeping forces can reduce military budgets for countries wishing to follow Costa Rica, which abolished its army in 1947. 
The proposed United Nations Security Insurance Agency (UNSIA), ${ }^{16}$ a partnership of the Security Council with insurance companies would assess country risks and collect premiums that would be pooled to train standing UN peace-keeping and humanitarian forces (Henderson, 1995). Reforming and expanding the Security Council is now on the UN's agenda. The UN General Assembly should take up all the alternative financing mechanisms, including those of the 2002 UN Monterrey Consensus, the Global Marshall Plan, so as to implement the Millennium Development Goals. The time has come for global taxes on arms sales, currency trading, airline tickets and e-mail to provide global public goods: education, healthcare, sounder international financial architecture and peacekeeping.

These human skills now have laid before us a rich array of potentials for astounding, widespread, shared prosperity, peace, restoring and our planet's ecosystems. These new visions and values underlie in the United Nations Millennium Development Goals, in the UN Global Compact; in the Prague Declaration on Humanizing Globalization; the Global Marshall Plan; the ILO's Report of the Commission on the Human Dimensions of Globalization; and the 16 principles of the Earth Charter, now ratified by hundreds of municipalities, companies and thousands of NGOs in over one hundred countries. The way forward and transition to peaceful sustainable societies is possible.

\section{References}

Ackerman, F. and Heinzerling, L. (2004) Priceless, New York, London: The New Press.

Allee, V. (2003) Increasing Prosperity Through Value Networks.

Altman, D. (2004) Neoconomy, Public Affairs, New York.

Axelrod, R. (1984) The Evolution of Cooperation, New York: Basic Books.

Batra, R. (2005) Greenspan's Fraud, Palgrave, New York: Macmillan.

Brandenburger, A.M. and Nalebuff, B.J. (1996) Co-opetition, New York: Currency Doubleday, Bantam Doubleday, Dell Publishing.

Coy, P. (2005) 'Why logic takes a backseat?', Business Week, 28 March.

Fox, J. (2005) 'Why Johnny can't save for retirement?', FORTUNE, 21 March.

Hotz, R.L. (2005) 'Anatomy of give and take', Los Angeles Times, 18 March.

Goshal, S. (2005) Bad Management Theories are Destroying Good Management Practices, Academy of Management Learning and Education, Vol. 4, No. 1, pp.75-91.

Henderson, H. (1995) 'The UN policy and financing alternatives', FUTURES, UK: Elsevier.

Henderson, H. (1996) Building a Win-Win World, San Francisco: Berrett-Koehler, p.56.

Henderson, H. (1999) Beyond Globalization: Shaping a Sustainable Global Economy, Kumarian Press.

Henderson, H. (2001) 'Information: the great leveler', World Affairs, Vol. 5, No. 2, pp.48-58.

Henderson, H. (2003a) 'G-8 economists in retreat', InterPress Service, Montevideo, New York, Rome, June.

Henderson, H. (2003b) 'Statisticians of the world unite', InterPress Service, November, www.sustentabilidade.org.br.

Henderson, H. (2004a) 'Abolish the Nobel prize?', InterPress Service, Rome, Montevidao, Washington, DC, December.

Henderson, H. (2004b) 'Education: key investments in the wealth of nations', Boston Research Center Newsletter, Fall-Winter, No. 23.

Henderson, H. (2005) 'L'Imposture', LeMonde Diplomatique, February. 
Henderson, H. and Ikeda, D. (2004) Planetary Citizenship, Los Angeles: Middleway Press.

Henderson, H. and Kay, A.F. (1998) 'Proposal for a truth in advertising assurance set-aside', Human Development Report, United Nations Development Program, New York.

Kuhn, T.S. (1962) The Structure of Scientific Revolutions, Chicago: University of Chicago Press.

Landes, D. (1998) The Wealth and Poverty of Nations, New York: Norton.

Leitaer, B. (2001) The Future of Money, London, UK: Ramdon House.

Loye, D. (2000) 'Darwin's lost theory of love', ToExel, New York.

Moore, J.F. (1996) The Death of Competition, New York: Harper-Collins.

Nadeau, R. (2003) The Wealth of Nature, Columbia University Press.

Nadeau, R. and Kafatos, M. (1999) The Non-Local Universe: the New Physics and Matters of the Mind, UK: Oxford University Press.

Perkins, J.B. (2004) Confessions of an Economic Hit Man, San Francisco: Berrett-Koehler.

Polanyi, K. (1945) The Great Transformation, Boston: Beacon Press.

Radermacher, F.J. (2004) Global Marshall Plan: A Planetary Contract, Global Marshall Plan Foundation, Hamburg, Germany.

Rosen, C., Case, J. and Staubus, M. (2005) Equity, Boston: Harvard Business School Press.

Sachs, J. (2005) The End of Poverty, London: Penguin Books.

Schumpeter, J.A. (1942/1947) Capitalism, Socialism and Democracy, New York: Harper and Row. Tainter, J. (1988) The Collapse of Complex Societies, New York: Cambridge University Press.

Wright, R. (2000) Non-Zero, Pantheon, NY.

\section{Notes}

1 www.thedarwinproject.com

2 'Bad for business?', The Economist, 17 February 2005.

3 www.dhf.uu.se

4 As a friend, I had the pleasure of discussing his theories with him over many dinners at my home in Princeton (Kuhn, 1962).

5 www.levy.org

6 InterPress Service, Rome, Montevidao, Washington, DC, December 2004, Hazel Henderson personal interview with Peter Nobel, quoted in 'Abolish The "Nobel” In Economics?'

7 www.ethicalmarkets.com

8 The Economist, 25 January 2005.

9 www.gri.org

10 www.gti.org

11 'Please go, Mr. Fazio', The Economist, 13 August 2005, p.13.

12 'The shift away from thrift', The Economist, 7 April 2005.

13 Outlines a way to reduce the volume of advertising fairly and without curbing freedom of speech (Henderson and Kay, 1998).

14 www.socialinvst.org

15 Available on DVD from www.ethialmarkets.com.

16 See www.hazelhenderson.com, click on UNSIA. 